\title{
THE EFFECT OF TEACHING STYLES AND THE MOTOR EDUCABILITY TO SERVE UNDER MINI VOLLEYBALL (EXPERIMENTAL STUDY AT MIN MEDAN)
}

\author{
YUSUF \\ , Sumatera Utara, Indonesia \\ Correspondence: Yusuf, Sumatera Utara, Indonesia. E-mail:
}

\begin{abstract}
This study aims to determine the effect of teaching styles and the motor educability to serve under mini volleyball at MIN Medan.In addition, this study also aimed to determine the effect of motor educability of both the teaching style. Teaching style in this study are the inclusion of teaching style and teaching of command style also high educability motor and low educability motors. Reseach carried aout in Class V MIN Medan academic year 20142015 (even semester). The research method is experimental design with treatment by the level of $2 \times 2$ with a sample of 76 students. The results of this study are as follows: (1) overall there are significant differences between the teaching styleof inclusion with teaching style command to increased volleyball servicing. (2) There is an interaction between teaching style with a motor educability to increased volleyball servicing. (3) For students who have a high educability motors, wich are taught by the teaching style inclusion is better than teaching style command to increased volleyball servicing. (4) There is no difference between teaching style inclusion with teaching style command for student who have a lower educability motors in volleyball service improvement.
\end{abstract}

Keywords: Teaching style, motor educability, servicing under mini volleyball.

\section{Pendahuluan}

Pendidikan merupakan salah satu faktor penting untuk mewujudkan cita-cita, melalui pendidikan seseorang dapat mengembangkan potensi yang ada dalam dirinya. Hal ini bisa dikatakan relevan karena pada dasarnya pendidikan merupakan usaha sadar dan terencana untuk mewujudkan suasana belajar dan proses pembelajaran agar peserta didik secara aktif mengembangkan potensi dirinya untuk memiliki kekuatan spiritual keagamaan, pengendalian diri, kepribadian, kecerdasan, akhlak mulia, serta ketrampilan yang diperlukan dirinya dan masyarakat dimasa mendatang. Dengan pendidikan yang terencana serta bimbingan yang baik tujuan pendidikan akan tercapai dengan baik pula. Potensi-potensi peserta didik akan berkembang sesuai dengan harapan.

Sekolah merupakan suatu lembaga formal yang tersistem sebagai usaha peningkatan prestasi anak didik, kegiatan proses belajar mengajar merupakan kegiatan yang pokok dari 
kegiatan pendidikan disekolah. Berhasil atau tidaknya kegiatan pendidikan disekolah ditunjukkan dari perubahan tingkah-laku, pengetahuan, sikap, maupun keterampilan siswa sebagai peserta didik.

Pendidikan Jasmani dan Kesehatan yang dituangkan dalam standar isi Pendidikan jasmani dan kesehatan mempunyai peranan sangat penting untuk membangun dan menciptakan bangsa yang sehat, kuat, terampil dan cerdas. Standar isi pendidikan jasmani dan kesehatan di sekolah yang dilakukan melalui berbagai kegiatan dapat meningkatkan kemampuan dan pertumbuhan baik pada bidang kognitif, afektif maupun psikomotor. Hal ini tidak terlepas dari cara (metode) mengajar yang sebaik-baiknya. Untuk mencapai tujuan yang diinginkan yaitu dengan penggunaan metode mengajar yang sesuai dengan tingkat usia dan perkembangan maupun lingkungan siswa.

Bola voli merupakan salah satu permainan atau cabang olahraga yang sangat digemari oleh masyarakat Indonesia dan perlu diajarkan pada pembelajaran pendidikan jasmani bahkan perlu ditingkatkan pada jejang yang lebih tinggi. Jenjang lebih lanjut dengan pembelajaran bola voli yang baik akan membantu siswa untuk memperoleh perkembangan motorik yang optimal. Disamping itu juga dapat membantu siswa untuk mengembangkan potensinya dalam permainan bola voli. Menurut Courtney Carter, bahwa bola voli adalah olahraga permainan yang memerlukan ketrampilan dan strategi. Dengan demikian, dengan pembelajaran bola voli penting di sekolah dasar untuk memperoleh perkembangan gerak khususnya pada permainan bola voli. Pembelajaran yang sesuai pada tahapan ini akan menentukan perkembangan selanjutnya, tinggal bagaimanakah cara pembelajaran bola voli yang akan diajarkan disekolah yang sesuai dengan tahap perkembangannya. Dengan alasan tersebutlah maka perlunya modifikasi pembelajaran bola voli yang disesuaikan dengan karakter perkembangan siswa.

Beberapa karakteristik dari modifikasi olahraga menurut Toho Cholik Mutohir dijelaskan bahwa : (1). Sesuai dengan perkembangan anak meliputi umur, tingkat kesegaran jasmani, status kesehatan, tingkat keterampilan dan berbagai pengalaman gerak sebelumnya. (2). Cukup aman dimainkan oleh anak. (3). Memiliki aspek alternatif, bukan sesuatu yang sifatnya mutlak, seperti ukuran berat, bentuk alat, ukuran lapangan yang digunakan, durasi permainan, posisi pemain, peraturan dan jumlah pemain. (4). Cukup relevan dan tepat untuk anak. Beberapa modifikasi yang telah dilakukan dalam permainan bola voli antara lain ukuran lapangan, jumlah-pemain, berat bola dan sistem pertandingan serta sistem kemenangan. Modifikasi permainan bola voli dewasa dikenal dengan istilah bola voli mini. Modifikasi yang sudah dilakukan meliputi jumlah pemain dari 6 pemain menjadi 4 orang pemain. Tinggi net diturunkan, skor pertandingan dari 21 menjadi 15, berat bola dan ukuran panjang dan lebar lapangan juga dimodifikasi. Tentu modifikasi tersebut masih dilakukan kajian yang mendalam lagi sehingga akan mendapatkan modifikasi yang sesuai dengan takaran usia dan tumbuh kembang anak atau kita kenal dengan istilah Development Apropriate Practice (DAP). Untuk lebih jelasnya dapat dilihat di di bawah ini: 


\begin{tabular}{|l|l|}
\hline Ukuran modifikasi lapangan bola voli \\
\hline No & Bola voli mini \\
\hline 1 & Jumlah Pemain 4 orang \\
\hline 2 & Ukuran lapangan ; Panjang : 12 meter, Lebar : 4.5 meter \\
\hline 3 & Berat bola : 210220 gram \\
\hline 4 & Tinggi net: 2.10 meter \\
\hline 5 & Skor pertandingan 15 \\
\hline 6 & Sistem 2 kali kemenangan (two winningsets) \\
\hline
\end{tabular}

(Sumber acuan : Toho Cholik Mutohir, Permainan Bola Voli Konsep,

Tehnik,Strategi dan Modifikasi

Dengan konsep modifikasi maka anak akan lebih menikmati permainan bola voli, karena mereka mampu melakukan smes, pasing, servis dan juga hadang bola, dengan kemampuan di level mereka Tehnik,Strategi dan Modifikasi)

\section{Hasil Belajar}

Hasil belajar pada hakekatnya merupakan wujud nyata dari sebuah pembelajaran yang diwujudkan pada perubahan tingkah laku yang berlangsung secara sadar dan melibatkan segenap aktivitas siswa adalah merupakan proses belajar mengajar, dapat dikatakan berhasil apabila siswa telah memahami proses belajar mengajar serta mampu mencapai tujuan yang telah ditetapkan. Hasil perubahan tingkahlaku dari proses belajar mengajar inilah yang merupakan tujuan dari proses pembelajaran dan disebut hasil belajar.

\section{a. Hasil Belajar}

Hasil belajar adalah perubahan tingkah laku yang berlangsung secara sadar dan melibatkan segenap aktivitas siswa adalah merupakan proses belajar mengajar dapat dikatakan berhasil apabila, siswa telah memahami proses belajar mengajar serta mampu mencapai tujuan yang telah ditetapkan. Hasil perubahan tingkah laku dari proses belajar mengajar inilah yang disebut hasil belajar. Demikian pula dengan hasilnya, bahwa hasil belajar seseorang itu tidak nampak sebelum orang tersebut melakukan sesuatu yang menampakkan perubahan, pengetahuan (kognitif), sikap (afektif) dan keterampilan (psikomotor) dalam bentuk tingkah laku yang dapat diamati.

\section{b. Belajar}

Belajar akan berhasil apabila seorang siswa dapat mengerti dan memahami isi pelajaran yang diterima dari seorang guru. Belajar yang efektif hasilnya merupakan pemahaman dan pengertian. Menurut JS. Husdarta dan Yudha M. Saputra, belajar dimaknai sebagai proses perubahan tingkah laku sebagai akibat adanya interaksi antara dengan lingkungannya. Tingkah laku itu mencakup aspek pengetahuan, ketrampilan dan sikap. Sedangkan Djamarah dan Aswan mengungkapkan bahwa 
belajar adalah proses perubahan tingkah laku berkat pengalaman dan latihan, dimana tujuan kegiatannya adalah perubahan tingkah laku baik yang menyangkut pengetahuan, keterampilan maupun sikap; bahkan meliputi segenap aspek organisme atau pribadi.

\section{c. Mengajar}

Apakah yang dimaksud dengan mengajar? Mengajar merupakan suatu proses yang sangat kompleks. Guru berperan tidak hanya sekedar menyampaikan informasi kepada siswa saja tetapi juga guru harus berusaha agar siswa mau belajar. Karena mengajar sebagai upaya yang disengaja,maka guru terlebih dahulu harus mempersiapkan bahan yang akan disajikan kepada siswa.

Upaya yang guru lakukan ini dimaksudkan agar tujuan yang telah dirumuskan dapat dicapai.menurut JS. Husdarta dan Yudha M. Saputra mengajar adalah upaya guru dalam memberi rangsangan, bimbingan, pengarahan, dan dorongan kepada siswa agar terjadi proses belajar.

\section{Gaya Mengajar}

Pendekatan yang sering dipergunakan dalam melaksanakan pembelajaran merupakan sesuatu yang istimewa, karena hal ini berkaitan dengan intuisi guru, spontanitas dan pemahaman bagaimana siswa belajar. Hal ini sejalan dengan pendapat Winarno yang menyatakan, metode adalah cara yang ada di dalam fungsinya merupakan alat untuk mencapai tujuan. Makin baik metode itu, makin efektif pula pencapaian tujuan. Untuk menetapkan terlebih dahulu apakah metode dapat disebut baik, diperlukan patokan yang bersumber dari beberapa faktor utama yang menentukan tujuan yang akan dicapai. Metode adalah prosedur atau operasi untuk mencapai tujuan. Oleh karena itu yang paling strategis dalam proses belajar mengajar adalah pemilihan dan penetapan metode pembelajaran sebelum proses tersebut dilaksanakan. Istilah gaya mengajar dalam pendidikan jasmani pertama sekali dikemukakan oleh Mosston. Dalam penerapan gaya mengajar Mosston ini terdapat tiga perangkat keputusan yang menyatakan urutan mengajar dan belajar. Ketiga perangkat keputusan ini adalah : (1) sebelum pertemuan, (2) selama pertemuan, dan (3) sesudah pertemuan. Untukitu salah satu cara untuk mengajarkan materi pendidikan jasmani di sekolah dasar agar berhasil dengan baik adalah dengan cara menggunakan gaya mengajar yang bervariasi yang dapat merangsang siswa dalam pengembangan gerak.

2.1.Gaya Mengajar Inklusi

Gaya mengajar inklusi adalah pedoman mengajar yang dipakai oleh guru dalam menyajikan materi pembelajaran secara keseluruhan secara rinci dipaparkan tingkat kesulitannya. Standar tugas ditentukan oleh guru, sedangkan tugas siswa adalah menunjukkan tingkatan tugas yang bervariasi untuk tugas yang sama. Siswa diberi kebebasan untuk memilih dan menentukan pada tingkat kesulitan mana siswa mulai belajar, serta diberi kebebasan juga untuk menentukan berapa kali siswa harus mengulangi gerakan dalam mempelajari suatu teknik gerakan dalam setiap pertemuan.

\section{Belajar Gerak}


Belajar gerak merupakan sebagian dari belajar secara umum. Tujuannya adalah untuk menguasai berbagai keterampilan gerak dan mengembangkannya agar keterampilan gerak yang dikuasai bisa dilakukan untuk menyelesaikan tugas-tugas gerak dalam mencapai sasaran tertentu misalnya gerak olahraga.

Menurut Singer belajar gerak adalah suatu perubahan penampilan atau perilaku potensial yang relatif permanen sebagai hasil dari latihan dan pengalaman masa lalu terhadap situasi tugas tertentu. Sedangkan Drowatzcy mendefenisikan belajar gerak adalah sebagai proses perubahan atau modifikasi individu sebagai hasil timbal balik antara latihan dan kondisi lingkungan. Sedangkan schmidt menjelaskan bahwa belajar adalah suatu proses perubahan merespon yang relatif permanen sebagai akibat latihan dan pengalaman.

\section{Permainan Bola Voli Mini}

Permainan bola voli mini adalah sejenis bola voli yang dimainkan di lapangan kecil dengan empat pemain tiap regunya, dengan peraturan yang disedehanakan. Bola voli mini menyajikan sejenis bola voli yang disesuaikan dengan kebutuhan dan kemampuan anakanak usia 9 sampai 12 tahun. Bola voli mini adalah cara yang baik untuk mempelajari keterampilan dasar. Dengan cara ini setiap pemain akan lebih banyak menyentuh atau memainkan bola.

Menurut M. Yunus "jumlah pemain bola voli mini dalam satu regu 4 anak ukuran lapangan $4 \times 8$ meter dan tinggi net 2,10 meter. Ukuran bola voli mini yang umum dipakai adalah nomor 4" Permainan bola voli mini dimainkan oleh dua regu. Kedua regu dipisahkan oleh jaring pantulan. Bola voli dimainkan dengan anggota badan terutama lengan atau tangan. Tujuan permainan bola voli mini adalah agar setiap regu melewatkan bola dengan baik melalui atas jaring sampai bola tersebut menyentuh lantai di daerah lawan dan mencegah agar bola yang dilewatkan tidak menyentuh lantai lapangan sendiri. Posisi bola pada saat latihan pemain kanan garis belakang melakukan servis sampai melewati atas jaring ke daerah lawan.

Masing-masing regu berhak memainkan bola tiga kali pantulan atau sentuhan kecuali perkenaan saat membendung untuk mengembalikan ke daerah lawan. Seorang pemain kecuali pembendung tidak diperkenankan memainkan bola dua kali berturut-turut. Dalam permainan bola voli mini di awali dengan pukulan servis dan diakhiri dengan satu regu memenangkan satu set dengan mencapai angka 25. Cara mendapatkan angka menggunakan Reali point apabila regu tersebut membuat kesalahan maka regu lawan mendapatkan point.

\section{Servis Bawah Permainan Bola Voli Mini}

Servis bawah adalah sentuhan atau pukulan bola dari bawah sampai melewati jaring ke daerah lawan atau upaya untuk memasukkan bola ke daerah lawan dengan pukulan satu tangan dari bawah sehingga melewati jaring ke daerah lawan. Servis ini sangat diperlukan dalam permainan bola voli mini karena teknik ini merupakan suatu senjata yang ampuh untuk menyerang. Secara umum, setiap jenis servis itu dibagi menjadi tiga tahap, yakni: 1) tahap pertama adalah melempar bola ke atas (throw-up), 2) tahap kedua memukul bola (hiiting the ball) dan 3) tahap ketiga adalah gerak lanjutan (follow-through). 
Sedangkan servis dalam bola voli dibagi pada 2 jenis yakni; 1) servis underhand (tangan bawah) dan 2) overhand floating (mengambang). Sedangkan Beutelsthal meembagi servis pada: 1) servis bawah dan 2) servis hook, 3) servis floting, dan 4) servis ploting menyamping

\section{Motor educability}

Motor educability artinya adalah kemampuan motorik yang merupakan ranah psikomotorik yang intinya adalah gerakan. Motor educability merupakan kemampuan seorang individu dalam mempelajari suatu keterampilan gerak yang baru. Kemar ini merupakan kemampuan potensial yang menunjukkan cepat tidaknya atau mudal knya seseorang menguasai suatu keterampilan gerak yang baru. Dengan kata lain dapat dinyatakan, kian tinggi tingkat motor educability seseorang maka kian mudah dan cepat orang tersebut menguasai suatu keterampilan.

\section{Metode}

Metode yang digunakan dalam penelitian ini adalah metode eksperimen dengan desain Faktorial 2 x 2, dengan jumlah sampel sebanyak 40 orang siswa. Seluruh sampel dibagi menjdi empat kelompok perlakuan, sehingga masing-masing kelompok sebanyak 10 siswa. Untuk mempermudah pengontrolan terhadap masing-masing kelompok perlakuan maka rancangan penelitian sebagai berikut:

\begin{tabular}{|c|c|c|}
\hline Gotor & Inklusi & Komando \\
Educability (B) & $\left(\mathrm{A}_{1}\right)$ & $\left(\mathrm{A}_{2}\right)$ \\
\hline Tinggi (B1) & & A2B1 \\
\hline Rendah(B2) & A1B1 & A2B2 \\
\hline Total & A1B2 & A2 \\
\hline
\end{tabular}

\section{Hasil}

Data hasil servis bola voli yang digunakan untuk analisis berupa data hasil dari 5 kali servis dari siswa setelah mengikuti program pembelajaran, baik gaya mengajar inklusi maupun gaya mengajar komando. Dari hasil servis tersebut diperoleh data tes akhir dari perlakuan sehingga merupakan hasil pengaruh dari pembelajaran yang dilakukan.

\section{Peningkatan Servis Bola voli Gaya mengajar inklusi secara keseluruhan}

Data peningkatan servis bola voli kelompok gaya inklusi secara keseluruhan, diperoleh rentang antara 2 sampai 5, di dapatkan rata-rata sebesar 3.45 simpangan baku sebesar 1,276 dan distribusi frekuensiberdasarkan program SPSS versi 21 sebagaimana 
tampak dalam table Distribusi frekuensi skor peningkatan servis bola voli kelompok gaya mengajar inklusi secara keseluruhan. 


\begin{tabular}{|ll|r|r|r|r|}
\hline & & Inklusi & \\
& & Frequency & Percent & Valid Percent & $\begin{array}{c}\text { Cumulative } \\
\text { Percent }\end{array}$ \\
\hline & 2 & 7 & 17,5 & 35,0 & 35,0 \\
& 3 & 3 & 7,5 & 15,0 & 50,0 \\
Valid & 4 & 4 & 10,0 & 20,0 & 70,0 \\
& 5 & 6 & 15,0 & 30,0 & 100,0 \\
& Total & 20 & 50,0 & 100,0 & \\
Missing & System & 20 & 50,0 & & \\
Total & & 40 & 100,0 & & \\
\hline
\end{tabular}

Berdasarkan tabel $4.2 \quad 50 \%$ (10 orang) memperoleh skor peningkatan servis bola voli diatas rata-rata, $15 \%$ (3 orang) pada rata-rata dan 35\% (7 orang) di bawah rata.

\section{Peningkatan Servis Bola voli Kelompok Gaya mengajar Komando Secara Keseluruhan}

Data peningkatan servis bola voli kelompok gaya mengajar komando secara keseluruhan, diperoleh rentang antara 2 sampai 4, di dapatkan rata-rata sebesar 2.85 simpangan baku sebesar 0.745 dan distribusi frekuensi sebagaimana tampak dalam tabel Distribusi frekuensi skor peningkatan servis bola voli kelompok gaya mengajar komando secara keseluruhan

\begin{tabular}{|ll|r|r|r|r|}
\hline & & Frequency & Percent & Valid Percent & $\begin{array}{c}\text { Cumulative } \\
\text { Percent }\end{array}$ \\
\hline & 2 & 7 & 17,5 & 35,0 & 35,0 \\
& 3 & 9 & 22,5 & 45,0 & 80,0 \\
Valid & 4 & 4 & 10,0 & 20,0 & 100,0 \\
& Total & 20 & 50,0 & 100,0 & \\
Missing & System & 20 & 50,0 & & \\
Total & & 40 & 100,0 & & \\
\hline
\end{tabular}

Berdasarkan tabel $\quad 65 \%$ (13 orang) memperoleh skor peningkatan servis bola voli diatas rata-rata, $35 \%$ (7 orang)

\section{Peningkatan Servis Bola voli Kelompok Motor Educability Tinggi dengan Gaya mengajar Inklusi}

Data peningkatan servis bola voli kelompok Motor Educability Tinggi dengan gaya mengajar inklusi, diperoleh rentang antara 4 sampai 5, di dapatkan rata-rata sebesar 4.6 simpangan baku sebesar 0.516 dan distribusi frekuensi sebagaimana tampak dalam tabel 
Distribusi frekuensi skor peningkatan servis bola voli kelompok Motor Educability Tinggi dengan gaya mengajar inklusi

\begin{tabular}{|ll|r|r|r|r|}
\hline & Frequency & Percent & Valid Percent & $\begin{array}{c}\text { Cumulative } \\
\text { Percent }\end{array}$ \\
\hline Valid & 4 & 4 & 10,0 & 40,0 & 40,0 \\
& 5 & 6 & 15,0 & 60,0 & 100,0 \\
Missing & Total & 10 & 25,0 & 100,0 & \\
Total & & 30 & 75,0 & & \\
\hline
\end{tabular}

Berdasarkan tabel $\quad 60 \%$ (6 orang) memperoleh skor peningkatan servis bola voli diatas rata-rata, $40 \%$ (4 orang)

\section{Peningkatan Servis Bola voli Kelompok Motor Educability Rendah dengan} Gaya mengajar Inklusi.

Data peningkatan servis bola voli kelompok Motor Educability rendah dengan gaya mengajar inklusi, diperoleh rentang antara 2 sampai 3 dengan ,rata-rata sebesar 2.3 simpangan baku sebesar 0.483 dan distribusi frekuensi sebagaimana tampak dalam tabel Distribusi frekuensi skor peningkatan servis bola voli kelompok Motor Educability Rendah dengan gaya mengajar inklusi.

\begin{tabular}{|ll|r|r|r|r|}
\hline & Frequency & Percent & Valid Percent & \multicolumn{1}{c|}{$\begin{array}{c}\text { Cumulative } \\
\text { Percent }\end{array}$} \\
\hline \multirow{3}{*}{ Valid } & 2 & 7 & 17,5 & 70,0 & 70,0 \\
& 3 & 3 & 7,5 & 30,0 & 100,0 \\
Missing & Total & 10 & 25,0 & 100,0 & \\
Total & & 30 & 75,0 & & \\
\hline
\end{tabular}

Berdasarkan tabel 4.5, 30\% (3 orang) memperoleh skor peningkatan servis bola voli diatas rata-rata, $70 \%$ (7 orang)

\section{Peningkatan Servis Bola voli Kelompok Motor Educability Tinggi dengan Gaya mengajar Komando}

Data peningkatan servis bola voli kelompok Motor Educability Tinggi dengan gaya mengajar komando, diperoleh rentang antara 2 sampai 3 , di dapatkan rata-rata sebesar 2.4 simpangan baku sebesar 0.516 dan distribusi frekuensi sebagaimana tampak dalam table Distribusi frekuensi skor peningkatan servis bola voli kelompok Motor Educability Tinggi dengan gaya mengajar komando. 
A21

\begin{tabular}{|ll|r|r|r|r|}
\hline & Frequency & Percent & Valid Percent & $\begin{array}{c}\text { Cumulative } \\
\text { Percent }\end{array}$ \\
\hline & 2 & 6 & 15,0 & 60,0 & 60,0 \\
Valid & 3 & 4 & 10,0 & 40,0 & 100,0 \\
& Total & 10 & 25,0 & 100,0 & \\
Missing & System & 30 & 75,0 & & \\
Total & & 40 & 100,0 & & \\
\hline
\end{tabular}

Berdasarkan tabel $4.6 \quad 40 \%$ (4 orang) memperoleh skor peningkatan servis bola voli diatas rata-rata, $60 \%$ (6 orang) pada rata-rata.

\section{Peningkatan Servis Bola voli Kelompok Motor Educability Rendah dengan Gaya mengajar Komando}

Data peningkatan servis bola voli kelompok Motor Educability rendah dengan gaya mengajar komando, diperoleh rentang antara 2 sampai 4 , di dapatkan rata-rata sebesar 3.3 simpangan baku sebesar 0.675 dan distribusi frekuensi sebagaimana tampak dalam tabel Distribusi frekuensi skor peningkatan servis bola voli kelompok Motor Educability rendah dengan gaya mengajar komando.

\begin{tabular}{|ll|r|r|r|r|}
\hline & A22 & & \\
& 2 & Frequency & Percent & Valid Percent & Cumulative Percent \\
\hline \multirow{2}{*}{ Valid } & 1 & 2,5 & 10,0 & 10,0 \\
& 3 & 5 & 12,5 & 50,0 & 60,0 \\
& 4 & 4 & 10,0 & 40,0 & 100,0 \\
Missing & Total & 10 & 25,0 & 100,0 & \\
Total & System & 30 & 75,0 & & \\
& & 40 & 100,0 & & \\
\hline
\end{tabular}

Berdasarkan tabel $4.7 \quad 40 \%$ (4 orang) memperoleh skor peningkatan servis bola voli diatas rata-rata, $50 \%$ (5 orang) pada rata-rata dan 10\% ( 1 orang) di bawah rata.

\footnotetext{
Perbedaan Peningkatan Servis Bola voli antara Gaya mengajar Inklusi dengan gaya mengajar Komando secara Keseluruhan

Berdasarkan hasil analisis varian (ANAVA) didapat $\mathrm{F}_{\mathrm{o}}=11,782$. Dengan demikian $\mathrm{F}_{\mathrm{o}}>\mathrm{F}_{\mathrm{t}}$, sehingga $\mathrm{H}_{\mathrm{o}}$ ditolak, sehingga dapat disimpulkan bahwa secara keseluruhan, terdapat perbedaan yang nyata antara gaya mengajar inklusi dengan komando terhadap peningkatan servis bola voli. Dengan perkataan lain bahwa peningkatan servis bola voli dengan menggunakan gaya mengajar inklusi $(\bar{X}=3,45 ; \mathrm{s}=1,276$ ) lebih baik dari pada gaya mengajarkomando $(\bar{X}=2.85 ; \mathrm{s}=0.745)$. Ini berarti hipotesis penelitian yang menyatakan
} 
bahwa secara keseluruhan peningkatan servis bola voli dengan menggunakan gaya mengajar inklusi lebih baik dibanding dengan menggunakan gaya mengajar komando.

\section{Interaksi Antara Gaya mengajar Latihan Dengan Motor Educability Terhadap Peningkatan Servis Bola voli.}

Berdasarkan hasil analisis varian tentang interaksi antara gaya mengajar latihan dan Motor Educability terhadap peningkatan servis bola voli terlihat pada tabel perhitungan anava di atas, bahwa harga hitung Fo interaksi $\mathrm{F}=83.782$ dan sig= 0.00 Tampak bahwa fungsi $\mathrm{F}$ hitung $>$ nilai sig sehingga Ho ditolak. Kesimpulannya bahwa terdapat interaksi antara gaya mengajar dengan Motor Educability terhadap servis bola voli.

Dengan terujinya interaksi tersebut, maka selanjutnya perlu dilakukan uji lanjut. Uji lanjut dimaksudkan untuk mengetahui tentang: (1) perbedaan peningkatan servis bola voli antara gaya mengajar inklusi dengan gaya mengajar komando bagi kelompok yang memiliki Motor Educability Tinggi; (2) perbedaan peningkatan servis bola voli antara gaya mengajar inklusi dengan gaya mengajar komando bagi kelompok memiliki Motor Educability rendah.

\section{Perbedaan Pengaruh Gaya mengajar Inklusi dan Gaya mengajar Komando Terhadap Peningkatan Servis Bola voli Bagi Kelompok Motor Educability Tinggi}

Kelompok perlakuan Motor Educability Tinggi dengan gaya mengajar latihan beban sisitem sirkuit $\left(\mathrm{P}_{1}\right)$ dibanding dengan kelompok perlakuan Motor Educability Tinggi dengan gaya mengajar komando $\left(\mathrm{P}_{2}\right)$, diperoleh $\mathrm{Q}_{\mathrm{o}}=2.85$ dan $\mathrm{Q}_{\mathrm{t}}=2,26$. Dengan demikian $\mathrm{Q}_{\mathrm{o}}$ lebih besar daripada $\mathrm{Q}_{\mathrm{t}}$, sehingga Ho ditolak, sehingga dapat ditafsirkan bahwa terdapat perbedaan peningkatan servis bola voli secara nyata antara gaya mengajar inklusi dengan gaya mengajar komando dengan tingkat motor educability rendah. Dengan perkataan lain bahwa mahasiswa yang mempunyai Motor Educability Tinggi dengan menggunakan gaya mengajar inklusi $(\bar{X}=4.6 ; \mathrm{s}=0.516)$ lebih baik dari pada gaya mengajarkomando $(\bar{X}=$ $2.4 ; \mathrm{s}=0.515)$ dalam peningkatan servis bola voli. Dengan demikian hipotesis penelitian dinyatakan bahwa Motor Educability Tinggi, gaya mengajar inklusi lebih baik dibanding dengan gaya mengajar komando dalam peningkatan servis bola voli.

\section{Perbedaan Pengaruh Gaya mengajar Inklusi dan Gaya mengajar Komando Terhadap Peningkatan Servis Bola voli Bagi Kelompok Motor Educability Rendah}

Gaya mengajar komando memberikan pengaruh yang nyata terhadap peningkatan servis bola voli pada kelompok yang memiliki Motor Educability rendah. Hal ini terbukti berdasarkan hasil uji lanjut dalan analisis varian (ANAVA) dengan menggunakan uji Tukey yang hasilnya sebagai berikut: Kelompok perlakuan Motor Educability rendah dengan gaya mengajar inklusi $\left(\mathrm{P}_{3}\right)$ dibanding dengan kelompok perlakuan Motor Educability rendah dengan gaya mengajar komando $(\mathrm{P} 4)$, diperoleh $\mathrm{Q}_{\mathrm{o}}=1.30$ dan $\mathrm{Q}_{\mathrm{t}}=2$ 2,26. Dengan perkataan lain bahwa mahasiswa yang mempunyai Motor Educability rendah dengan menggunakan gaya mengajar Komando $(\bar{X}=3.3 ; \mathrm{s}=0.675)$ lebih baik dari pada gaya mengajar inklusi ( $\bar{X}=2.3 ; \mathrm{s}=0.483$ ) dalam peningkatan servis bola voli. Dengan demikian $\mathrm{Q}_{\mathrm{o}}$ lebih kecil daripada $\mathrm{Q}_{\mathrm{t}}$, sehingga Ho diterima atau tidak terdapat perbedaan yang berarti. 


\section{Pembahasan}

Dari hasil pengujian keempat rumusan hipotesis ternyata hasilnya menunjukkan bahwa hipotesis 1 (satu), 2 (dua) tersebut teruji. Sedangkan rumusan hipotesis yang ke 3 (tiga) menunjukkan bahwa secara statistik tidak terdapat perbedaan yang signifikan. Secara rata-rata bahwa skor gaya mengajar komando lebih tinggi peningkatannya bagi kelompok yang memiliki Motor Educability rendah. Hal ini menunjukkan bahwa kedua bentuk latihan tersebut memberikan pengaruh yang sama atau seimbang terhadap peningkatan servis bola voli.

Hipotesis ketiga menunjukkan tidak terbukti atau belum dapat teruji kebenarannya karena tidak didukung oleh data yang terkumpul. Hal ini sesuai dengan kajian teori dan kerangka berfikir yang telah dikemukakan pada bab II tetap masih menjadi dugaan karena belum dapat dibuktikan secara empirik. Dengan demikian, diperlukan pembahasan terhadap berbagai kemungkinan yang menyebabkan tidak terbuktinya hipotesisi tersebut. Adapun kemungkinan yang terjadi sebagai berikut:

1. Waktu latihan. Lamanya waktu latihan diduga sebagai salah satu penyebab tidak terbuktinya hipotesisi ketiga. Frekwensi latihan dan waktu latihan diduga kurang memadai. Perlakuan diberikan kurang lebih 4 x pertemuan (12 x 35 menit).

2. Aktivitas sampel. Diduga siswa ada yang melakukan aktivitas olahraga lain diluar perlakukan yang diberikan, walaupun sebelum penelitian dimulai telah diberitahukan agar jangan melakukan kegiatan olahraga yang selama masa penelitian.

3. Faktor fisik lain. Dimungkinkan pula masih rendahnya komponen fisik lainnya yang memiliki kontribusi terhadap servis bola voli seperti, koordinasi dan kelentukan serta perbedaan tingkat daya ledak otot tungkainya.

4. Faktor motivasi. Tidak terkontrolnya unsur motivasi yang kemungkinan berpengaruh pada saat proses latihan, sebab motivasi juga sangat mempengaruhi seseorang dalam melakukan aktivitas apapun.

5. Minat. Minat merupakan satu unsur psikologi yang diduga turut mempengaruhi penelitian, dimana minat merupakan salah satu pendorong seseorang untuk memiliki suatu aktivitas tertentu. Jika seseorang memiliki minat terhadap suatu aktivitas, maka ia akan lebih serius untuk melakukan aktivitas tersebut.

Secara keseluruhan maka gaya mengajar inklusi memiliki pengaruh yang lebih baik dibanding dengan gaya mengajar komando, sedangkan bagi yang memiliki Motor Educability Tinggi hendaknya memilih gaya mengajar inklusi jika ingin meningkatkan servis bola voli. Sedangkan bagi yang memiliki Motor Educability rendah, dapat melakukan kedua latihan untuk meningkatkan servis bola voli, tetapi cenderung akan lebih baik jika melakukan komando, hal ini disebabkan perbedaan jumlah rata-ratanya.

\section{Referensi}

A Schmidt, Ricardt. Motor Learning and Control: a behavior emphasis. Champaigh Illinois: Human Kinetics Publisher, Inc., 1988.

Bahri Djamarah, Syaiful dan Aswan Zain, Strategi Belajar Mengajar. Jakarta: PT Rineka Cipta, 1997. 
Beutelstahl, Dieter., Belajar Bermain Bola volley. Bandung: CV Pioner Jaya, 2005.

Carter,Courtney., Volley Ball : High Performance Sport Conditioning. USA: Human Kinetics, 2001.

Cholik Mutohir, Toho., Permainan Bola Voli Konsep, Tehnik,Strategi dan Modifikasi, Jakarta: Graha Pustaka Media Utama, 2012.

$\mathrm{K}$ Donald, Mathews.,Measurment in Physical Education. London, Philedephia: Sauders Company, 1985.

Linson, Tom., How To Differentiate Instruction in Mixed Ability Classroom. Second Edition. New Jersey: Person Education, 2005.

Lutan, Rusli, Perkembangan dan Belajar Mengajar Gerak. Dinas P \& K Direktorat Jenderal Pendidikan Dasar dan Menengah,1995.

L. Viera, Barbara dan Bonne Jill Fergusson, Bolavoli tingkat Pemula. Jakarta: PT Rajagrafindo Persada, 2004.

M, Mosston, Teaching Physical Education (2nd ed), Columbus, OH: Merril, 1981.

M. Yunus, Drs., Olahraga Pilihan Bolavoli. Jakarta: Departemen P \& K, 1992.

Samsudin, Pembelajaran Pendidikan Jasmani dan Olahraga dan Kesehatan. Jakarta: Litera, 2008.

Widiastuti, Tes dan Pengukuran Olahraga. Jakarta: PT. Bumi Timur Jaya, 2011. 